\title{
Intraperitoneal Blood Transfusion in African Adults with Hookworm Anaemia
}

\author{
J. M. FOWLER,* M.B., B.S., M.R.C.P. ; R. KNIGHT,* M.B., B.S., M.R.C.P., D.T.M.\&H. \\ KANTI M. PATEL,* M.B., B.S., M.R.C.P.BD., M.R.C.P.GLASG., D.T.M.\&H., D.C.H.
}

Brit. med. F., 1968, 3, 220-221

\begin{abstract}
Cummary: Twenty-nine pationts were given an intraperitoneal transfusion of blood. The procedure was found to be free of serious complications. Study of the absorption of ${ }^{51} \mathrm{Cr}$-labelled cells from the peritoneum in 14 patients showed that between 35 and $100 \%$ of the blood was absorbed intact in 6 to 10 days. Intraperitoneal transfusion may be indicated as an alternative or as an addition to exchange transfusion in severe hookworm anaemia.
\end{abstract}

\section{Introduction}

The early management of patients with severe hookworm anaemia presents a very common and challenging problem in many parts of the tropics. In patients with a haemoglobin level below $4 \mathrm{~g} . / 100 \mathrm{ml}$. there is a considerable mortality during the first few days after admission to hospital ; many of them are in overt cardiac failure or are precipitated into it by injudicious treatment. Blood transfusion in some form is essential, but the intravenous route carries the definite risk of circulatory overload. Mollison (1961) suggests that in chronic severe anaemia an inital transfusion of not more than $250 \mathrm{ml}$. of packed cells should be given over a period of four to six hours. This method is impracticable or difficult without very careful supervision. Exchange transfusion is probably the ideal method (Fullerton and Turner, 1962 ; Lancet, 1966), but also requires skilled attention. In rural hospitals, where many of these patients are admitted, a simple, safe, and effective method is obviousiy needed.

An alternative method to intravenous blood transfusion is to deliver the blood into the peritoneum. It has long been known that red blood cells are absorbed intact from the peritoneum both in animals (von Recklinghausen, 1863 ; Courtice et al., 1953) and in man (Mollison, 1961). Absorption occurs mainly through the lymphatics situated on the peritoneal surface of the diaphragm, and thence into the bloodstream via the anterior mediastinal and right lymphatic ducts. Rochlin and Blakemore (quoted by Mellish and Wolman, 1958), working on the dog, measured the survival time of red cells absorbed through the peritoneum, and compared it with the survival of cells injected intravenously. No difference was found.

In children the intraperitoneal route for transfusion has been widely used (Macdougall, 1958 ; Mellish and Wolman, 1958). Absorption has been measured quantitatively in children by Mollison (1961), who found that $86 \%$ was absorbed within six days. The therapeutic value of peritoneal transfusion in adults has not yet been evaluated.

\section{Methods}

Fourteen patients (seven men and seven women) were studied, their ages ranging from 25 to 70 , with a mean of 39.1 years.

\footnotetext{
- Department of Medicine, Makerere University College, Kampala, Uganda.
}

To reduce the risk of possible gonadal irradiation all the women studied were postmenopausal. The haemoglobin level on admission ranged from 2 to $5.6 \mathrm{~g} . / 100 \mathrm{ml}$., with a mean of $3.4 \mathrm{~g}$. Stool examination showed numerous hookworm ova in all cases. In eight patients the jugular venous pressure was raised more than $5 \mathrm{~cm}$. above the sternal angle. Most of these patients showed liver enlargement and peripheral oedema.

The red cells for intraperitoneal injection were tagged with $80 \mu \mathrm{Ci}$ of ${ }^{51} \mathrm{Cr}$-labelled sodium chromate, the method of Veall and Vetter (1958) being used. In two cases the donor cells were labelled, and in 12 the patient's own red cells. In all cases at least $6 \mathrm{ml}$. of red cells was labelled. Radioactivity was measured in a well-type scintillation counter, 3-ml. volumes being used. The red cells were haemolysed with saponin.

At the end of each study the plasma volume was determined with Evans blue-T1824, as described by Dacie and Lewis (1963) ; haematocrits were measured by the micromethod. Red cell absorption was calculated from the radioactivity of the preinjection standard and the total body red cell radioactivity, the latter being the product of the red cell volume, determined by the haematocrit from the plasma volume, and the radioactivity of the sample. Sample counts were corrected for loss of radioactivity due to elution and lysis of aged cells, the figures of Lajtha (1961) being used. In seven patients the rate of absorption was studied. To do this the plasma volume at the beginning of the study was measured and the red cell volumes for each day were estimated by interpolation between the initial and final red cell volumes, assuming a linear relationship. The correction for whole-body haematocrit was not applied, as there is doubt about its validity in the presence of splenomegaly, an almost universal finding in our patients.

\section{Technique of Transfusion}

Patients were premedicated with $10 \mathrm{mg}$. of morphine intramuscularly. With the patient lying supine a point on the skin was chosen just above or below the umbilicus in the midline; this was infiltrated with $2 \%$ procaine. Previous palpation and percussion of the chosen site was always undertaken to exclude an underlying enlarged viscus. The needle of a transfusion-giving set, filled with warmed saline, was inserted into the fibrous tissue of the linea alba and the tap on the set opened. The needle was then introduced further until saline ran freely into the peritoneum. ${ }^{51} \mathrm{Cr}$-labelled red cells were now injected into the tubing of the giving set, and the bottle of saline was replaced by the donor whole blood, which had been previously warmed to body temperature in a water bath; 1 or 2 pints ( 570 or $1,140 \mathrm{ml}$.) of blorid were transfused, taking only 5 to 10 minutes. A few patients experienced a little pain or discomfort in the abdomen or shoulder tip. However, this was never severe enough for the transfusion to be stopped. At no time was respiratory distress noticed during the transfusion. 


\section{Results}

The Table gives the percentage absorption of the transfused red blood cells on the day on which each study was completed. In the first two patients studied donor cells were labelled with ${ }^{51} \mathrm{Cr}$ and the absorption was very low. In subsequent studies the patient's own red blood cells were used to eliminate variation in the age and quality of donor cells, which might affect the results. The Chart shows the mean percentage absorption, with the range, on each day.

\section{Intraperitoneal Blood Transfusion}

\begin{tabular}{|c|c|c|c|c|c|}
\hline $\begin{array}{l}\text { Case } \\
\text { No. }\end{array}$ & $\begin{array}{l}\text { Absorption } \\
\text { (\%) }\end{array}$ & $\begin{array}{c}\text { Final } \\
\text { Day }\end{array}$ & $\begin{array}{l}\text { Case } \\
\text { No. }\end{array}$ & $\begin{array}{c}\text { Absorption } \\
(\%)\end{array}$ & $\begin{array}{l}\text { Final } \\
\text { Day }\end{array}$ \\
\hline 1 & 14 & 5) Donor & 8 & 96 & 9 \\
\hline $\begin{array}{l}2 \\
3 \\
4 \\
5 \\
6 \\
7\end{array}$ & $\begin{array}{r}12 \\
85 \\
74 \\
35 \\
100 \\
78\end{array}$ & $\begin{array}{c}7 \int \text { labelled } \\
10 \\
7 \\
8 \\
7 \\
6\end{array}$ & $\begin{array}{r}9 \\
10 \\
11 \\
12 \\
13 \\
14\end{array}$ & $\begin{array}{l}84 \\
82 \\
61 \\
52 \\
80 \\
82\end{array}$ & $\begin{array}{l}7 \\
6 \\
6 \\
9 \\
7 \\
7\end{array}$ \\
\hline
\end{tabular}

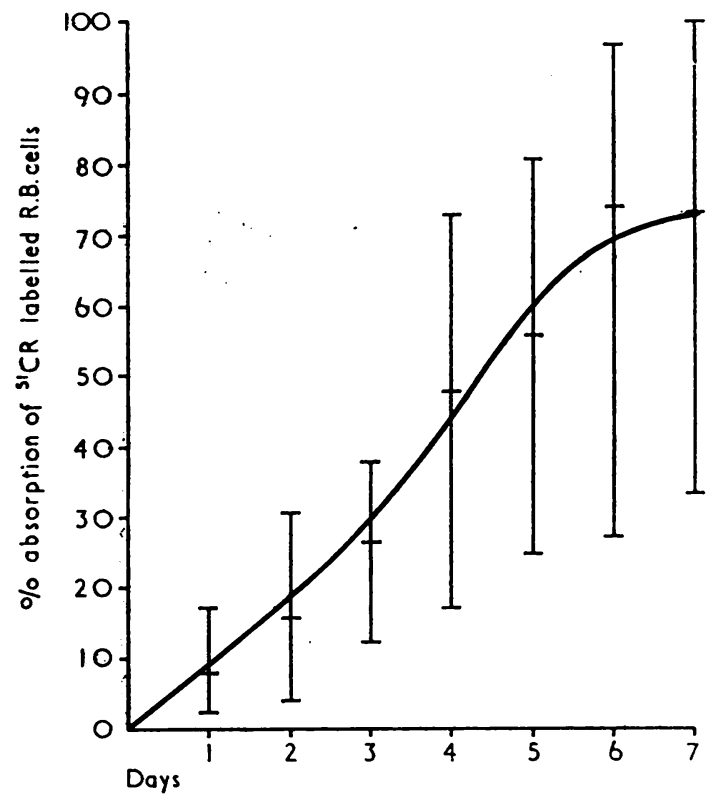

Mean percentage absorption and range of labelled red cells on each day following transfusion.

Blood volume studies in seven patients before transfusion gave values between 58 and $109 \mathrm{ml} . / \mathrm{kg}$., with a mean of $74.8 \mathrm{ml}$. After transfusion the values varied from 61.8 to $80.2 \mathrm{ml} . / \mathrm{kg}$., with a mean of $70.3 \mathrm{ml}$. In four patients the blood volumes rose, and in three, all in heart failure, the values fell.

\section{Discussion}

The percentage absorption of blood from the peritoneal cavity into the circulation is shown in the Table and Chart. The absorption occurred continuously in a linear manner from the time of transfusion until the sixth to eighth day, when the rate of absorption slowed down. This is in agreement with Mollison's 1961 data.

In 15 additional patients with hookworm anaemia an intraperitoneal transfusion was given, up to 3 pints (1.7 litres) of whole blood at a time being used, in order to assess the safety of the procedure. Apart from some discomfort no ill effects were observed, except in one patient who died four days after the transfusion. A post-mortem diagnosis of aleukaemic leukaemia was made, in addition to heavy hookworm infestation. It is of great interest that in this case the peritoneum was free of blood at necropsy.

Ideas on the proper management of severe hookworm anaemia are varied. In high output cardiac failure due to anaemia digitalis is " notoriously ineffective" (Lown and Levine, 1955). Furthermore, in severe chronic hookworm anaemia the blood volume is usually normal or slightly reduced (Jalili and Hindawi, 1962). Consequently the administration of diuretics may calise a sudden drop in the cardiac output in a patient who previously had been able to maintain an adequate circulation. Digoxin and diuretics are often given empirically. Their value has not been properly assessed in hookworm anaemia, and it is our impression that they may be dangerous. If the patient is ill enough to require blood transfusion the slow infusion of packed cells by the intravenous route is probably often dangerous. The ideal method, which should be used wherever possible, is exchange transfusion. If, however, this method is not used, peritoneal transfusion offers a satisfactory and safe alternative. Furthermore, peritoneal transfusion can be used as a supplement to exchange transfusion. After the exchange transfusion a further 1 or 2 pints $(570$ or $1,140 \mathrm{ml}$.) of blood, perhaps including the patient's own cells removed during the exchange, can safely be put into the peritoneum.

This work was supported by a grant from Makerere University College, Kampala, Uganda.

\section{REFERENCES}

Courtice, F. C., Harding, J., and Steinbeck, A. W. (1953). Aust. F. exp. Biol. med. Sci. 31, 215 .

Dacie, J. V., and Lewis, S. M. (1963). Practical Haematology, 3rd ed. London.

Fullerton, W. T., and Turner, A. G. (1962). Lancet, 1, 75

Jalili, M. A., and Hindawi, A. Y. (1962). Brit. Heart \%., 24, 595. Lajtha, L. G. (1961). The Use of Isotopes in Haematology. Oxford. Lancet, 1966, 2, 270.

Lown, B., and Levine, S. A. (1955). Current Concepts in Digitalis Therapy, pp. 9,10 . London.

Macdougall, L. G. (1958). Brit. med. 7., 1, 139

Mellish, P., and Wolman, I. J. (1958). Amer. 7 . med. Sci., 235, 717 Mollison, P. L. (1961). Blood Transfusion in Clinical Medicine, 3rd ed., pp. 115,120 . Oxford.

eall, N., and Vetter, H. (1958). Radioisotope Techniques in Clinical Research and Diagnosis. London.

von Recklinghausen, F. (1863). Virchows Arch. path. Anat., 26, 172. 